\title{
Isolation of Intestinal Glucose Uptake Inhibitor from Punica granatum L.
}

\author{
Hye Kyung Kim ${ }^{1}$, Soon-Sun Baek ${ }^{2}$, and Hong-Yon $\mathrm{Cho}^{3 \dagger}$ \\ ${ }^{I}$ Department of Food and Biotechnology, Hanseo University, Chungnam 356-706, Korea \\ ${ }^{2} R \& D$ Headquarters Ginseng Research Institute, Korea Ginseng Corporation, Daejon 305-805, Korea \\ ${ }^{3}$ Department of Food and Biotechnology, College of Science and Technology, \\ Korea University, Chungnam 339-700, Korea
}

\begin{abstract}
Inhibition of intestinal glucose uptake is beneficial in reducing the blood glucose level for diabetes. To search for an effective intestinal glucose uptake inhibitor from natural sources, 70 native edible plants, fruits and vegetables were screened using Caco-2 cells and fluorescent D-glucose analog 2-[N-(7-nitrobenz-2-oxa-1,3-diazol-4-yl) amino]-2-deoxy-D-glucose (2-NBDG). A compound that was able to inhibit glucose uptake was isolated from methanol extract of Punica granatum L. and called PG-1a. PG-1a appears to be a phthalic acid-diisononyl ester-like compound (PDE) with molecular weight of 418. The inhibitory effect of PG-1a on intestinal glucose uptake was dose-dependent with $89 \%$ inhibition at $100 \mu \mathrm{g} / \mathrm{mL}$. Furthermore, the intestinal glucose uptake inhibitory effect of PG-1a was 1.2-fold higher than phlorizin, a well known glucose uptake inhibitor. This study suggests that PG-1a could play a role in controlling the dietary glucose absorption, and that PG-1a can effectively improve the diabetic condition, and may be used as an optional therapeutic and preventive agent.
\end{abstract}

Key words: Punica granatum L., glucose uptake, 2-NBDG, Caco-2 cell, brush border membrane vesicle

\section{INTRODUCTION}

Diabetes is a disease characterized by chronic hyperglycemia, which is not only a symptom of diabetes but also a pathogenic factor leading to a number of microvascular and macrovascular complications $(1,2)$. Management of diabetes at present relies mainly on reduction of dietary carbohydrate intake and the use of hypoglycemic agents to lower the blood glucose levels. Control over the intestinal absorption of glucose would help to improve levels of glucose in the blood stream and reduce complications. One of the most effective ways to control the postprandial blood glucose level is to inhibit $\alpha$-glucosidase or amylase, and therefore a number of inhibitors of these enzymes have been developed (3-5). However, inhibitors of these enzymes are not able to prevent glucose absorption when glucose itself has been ingested. Hence, it might be important to inhibit intestinal glucose absorption as well as glucosidase or amylase activity for the regulation of postprandial blood glucose levels. We have investigated the intestinal glucose uptake/transport inhibitor from various Korean edible plants, among which the methanol extract of pomegranate (Punica granatum L.) was selected for the isolation and purification of a glucose uptake inhibitor.

Punica granatum L. (PG) is an edible fruit cultivated in many countries, including Afghanistan, India, China, Russia, and some parts of the United States. Pharmacological properties of PG extracts have been scrutinized, with anti-microbial (6), anti-parasitic (7), antiviral (8), anti-cancer (9) effects noted. An extract of the flowers lowers blood sugar in rodents (10), and the fresh juice inhibits LDL oxidation and atheromatous plaque formation in rodents and humans (11).

In this study, we used solvent partition, silica gel column chromatography, thin-layer chromatography (TLC), and high performance liquid chromatography (HPLC) to identify a potent inhibitor of intestinal glucose uptake from Punica granatum L. (PG). The isolated compound was then analyzed by EI-MS and ${ }^{13} \mathrm{C} /{ }^{1} \mathrm{H}-\mathrm{NMR}$ to elucidate its putative chemical structure. For the measurement of intestinal glucose uptake, we used a human intestinal epithelial cell line, Caco-2, and fluorescent D-glucose analog 2-[N-(7-nitrobenz-2-oxa-1,3-diazol-4-yl)amino]2-deoxy-D-glucose (2-NBDG) as a tracer of intestinal glucose uptake. Caco-2, which is widely used to investigate the intestinal nutrient transport in vitro, is a human colon adenocarcinoma cell line that spontaneously exhibits various enterocytic characteristics such as brush border enzymes and glucose transporters (12). 2-NBDG is a new fluorescent derivative of glucose which is readily incorporated and metabolized into living cells, yield- 
ing a non-fluorescent derivative (13). Several studies suggested a potential use for the 2-NBDG in measurement of glucose uptake and viability in cell cultures using HepG2 human hepatocarcinoma cells, L6 rat skeletal cells, 3T3 adipocytes, erythrocytes, coronary endothelial cells, cardiomycetes, human lung fibroblasts, and rabbit enterocytes (14-20). Therefore, the effects of intestinal glucose uptake inhibitor isolated from PG were investigated using Caco-2 cells and NBDG.

\section{MATERIALS AND METHODS}

\section{Samples}

70 Korean plants were obtained from a local market (Gyeong-dong market, Seoul, Korea) or oriental medicine store in Seoul, Republic of Korea. Samples were identified by the Division of the Oriental Medicine, Semyung University, and the voucher of the specimens was preserved. Each sample was blanched for $5 \mathrm{~min}$ to inactivate enzymes, homogenized with Ultra-Turrax (IKA-Lab, Muhsamstrasse, Berlin, Germany), and centrifuged at $10,000 \times g$ for $30 \mathrm{~min}$. The samples were extracted with various solvents (hexane, acetone, methanol and hot water) for $2 \mathrm{hr}$ and lyophilized.

\section{Cell culture}

Caco-2 cells obtained from American Type Culture Collection (Rockville, MD, USA) were cultured in Dulbecco's modified Eagle's medium (DMEM) with $10 \%$ fetal bovine serum (Gibco Life Technologies, Grand Island, NY, USA) and 1\% antibiotic-antimycotic (Gibco Life Technologies). The cells were incubated at $37^{\circ} \mathrm{C}$ in a humidified atmosphere of $5 \% \mathrm{CO}_{2}$ in air and the medium was changed every other day.

\section{Glucose uptake in Caco-2 cell}

Cells were seeded on 24-well plate at a density of $6 \times 10^{4}$ cells/well and cultured for $13 \sim 14$ days. Uptake experiments were performed using PBS containing 100 $\mu \mathrm{M}$ 2-NBDG (Invitrogen, Eugene, OR, USA) and PG $(0.1 \mathrm{mg} / \mathrm{mL})$ at $37^{\circ} \mathrm{C}$ for $120 \mathrm{~min}$. After incubation, the cells were washed with ice-cold PBS to stop the uptake. The 2-NBDG fluorescence intensity was measured with a spectrofluorometer (Excitation: $485 \mathrm{~nm}$, Emission: 535 nm, TECAN Austria GmbH, Salzburg, Austria). The cell viability was determined with MTT assay and the glucose uptake inhibitory effect was adjusted as the viable cell mass.

\section{Isolation of glucose uptake inhibitor, PG-1a}

Pomegranates (Punica granatum, PG) were purchased from the Gyeong-dong market in Seoul, Korea. The dried fruits of PG $(1 \mathrm{~kg})$ were powdered and extracted with methanol at room temperature for 5 days. Filtrate of the methanol extract $(560 \mathrm{~g})$ was evaporated at $40^{\circ} \mathrm{C}$ and was dissolved in deionized water and partitioned 4 times with hexane, chloroform, and ethyl acetate. The methanol residue fraction $(20 \mathrm{~g})$ with high inhibitory effect on intestinal glucose uptake was then subjected to a silica gel $60 \mathrm{G}$ column $(5.5 \times 45 \mathrm{~cm})$ by gradient elution with a mixture of the solvents $\left(\mathrm{CHCl}_{3}-\mathrm{MeOH}\right)$ at a flow rate of $2 \mathrm{~mL} / \mathrm{min}$, and resulted in 18 subfractions. The subfractions $(3.5 \mathrm{~g})$ that exerted the highest inhibitory effect on glucose uptake were rechromatographed on silica gel column $(4 \times 35 \mathrm{~cm})$ with the same eluant at a flow rate of $0.5 \mathrm{~mL} / \mathrm{min}$, and the fractions that showed most inhibitory effect were purified by successive preparative thin-layer chromatography (TLC) on an ODS-gel plate $(20 \times 20 \mathrm{~cm}$, Merk Co., Darmstadt, Germany) using methanol and water $(4: 1, \mathrm{v} / \mathrm{v})$ as developing solvents. High-performance liquid chromatography (HPLC, Waters Co., Milford, MA, USA) equipped with analytical column of $\mu$-Bondapak ${ }^{\mathrm{TM}} \mathrm{C}_{18}$ type (reverse phase, $7.8 \times 300$ $\mathrm{mm}$ ) was used for the further purification. The data were collected over the range 190 $800 \mathrm{~nm}$ and detection was performed at $228 \mathrm{~nm}$. Analytical separations were carried out at flow rate of $2.0 \mathrm{~mL} / \mathrm{min}$ using a 65 min linear gradient of $90 \sim 100 \%$ methanol in distilled water.

\section{Structural analysis of PG-1a}

The putative chemical structure of the isolated glucose uptake inhibitor was analyzed by NMR analysis. ${ }^{1} \mathrm{H}$ and ${ }^{13} \mathrm{C}$-NMR spectra were measured on a Bruker model Avance-500 (Bruker, Rheinstetten, Germany) instrumented at 500 and $125 \mathrm{MHz}$, respectively. The sample $(5 \mathrm{mg})$ was dissolved in methyl-d3 alcohol-dl (MeOD), and analyzed with tetramethylsilane $\left(\delta_{\mathrm{H}} 0.00 ; \delta_{\mathrm{C}} 0.00\right)$ as an international standard. Electron ionization mass (EI-MS, JEOL, Tokyo, Japan) was operated at $70 \mathrm{eV}$ and $250^{\circ} \mathrm{C}$ in chamber, and sample $(0.3 \mathrm{mg})$ dissolved in methanol was analyzed. The sample $(0.3 \mathrm{mg})$ dissolved in meta nitrobenzyl alcohol (Meta MBA) was applied to fast atom bombardment mass (FAB-MS, JEOL) equipped with $\mathrm{Xe}$ gas and at room temperature.

\section{Preparation of enterocytes}

An approximately $3 \mathrm{~cm}$ long segment of the duodenum from ICR mice was excised and washed in ice-cold phosphate buffered saline (PBS) containing $0.1 \mathrm{mM}$ dithiothreitol (DTT). The tissue was then incubated with Hank's salt solution supplemented with $1.5 \mathrm{mM}$ EDTA and $0.5 \mathrm{mM} \mathrm{DTT}$ at $37^{\circ} \mathrm{C}$ for $20 \mathrm{~min}$. The cells were collected, and incubation of this tissue was repeated to collect more cells. The cells were pelleted by low speed centrifuge $(700 \times g)$. 


\section{Cell viability assay}

The 3-(4,5-methylthiazol-2yl)-2,5-diphenyltetrazolium bromide (MTT) assay was performed to determine the toxicity of isolated glucose uptake inhibitor, PG-1a. Purified PG-1a $(100,200$, and $500 \mu \mathrm{g} / \mathrm{mL})$ was treated to isolated enterocytes and cultured for $24 \mathrm{hr}$. MTT (5.0 $\mathrm{mg} / \mathrm{mL}$ ) solution was added to each well and incubated for $4 \mathrm{hr}$ at $37^{\circ} \mathrm{C}$. Formazan formed by viable cells was dissolved with dimethyl sulfoxide (DMSO) and absorbance at $570 \mathrm{~nm}$ was determined by microplate reader (Bio-Tek, Winooski, VT, USA).

\section{Statistical analysis}

Results were presented as mean $\pm \mathrm{SD}$, and the data were analyzed by ANOVA followed by Turkey HSD's post-hoc test. A level of $p<0.05$ was considered as statistically significant.

\section{RESULTS AND DISCUSSION}

To search for an effective intestinal glucose uptake inhibitor from natural sources, 70 native edible plants, fruits and vegetables were screened using Caco- 2 cells, a well-accepted model of human intestinal absorption (Table 1). Among the screened extracts, the methanol extract of Punica granatum L. (PG) exhibited the highest inhibitory effect when compared with that of other extracts (Table 1).

Punica granatum L. (PG) fruit, commonly known as pomegranate, is widely consumed fresh and in beverage

Table 1. Inhibitory activity of various edible plants on intestinal glucose uptake

\begin{tabular}{lccr}
\hline \multirow{2}{*}{ Plants used for screening } & \multicolumn{3}{c}{$\begin{array}{c}\text { Glucose uptake inhibitory } \\
\text { effect (\%) }\end{array}$} \\
\cline { 2 - 4 } & Fr. A & Fr. B & Fr. C \\
\hline Punica granatum & 35.3 & 38.0 & 29.0 \\
Rosa rugosa & 31.3 & 22.5 & -6.2 \\
Citrus unshiu & 30.6 & 12.5 & 7.7 \\
Eucommia ulmoides (leaf) & 30.0 & 8.3 & -9.4 \\
Eucommia ulmoides (bark) & 26.2 & -4.4 & -6.7 \\
Diospyrus kaki & 25.0 & 28.0 & 3.9 \\
Angelica gigas & 25.0 & 6.9 & -2.8 \\
Green tea & 23.6 & 29.5 & 12.0 \\
Comus officinalis & 28.1 & 16.4 & 13.2 \\
Zizyphus jujube var. intermis & 22.3 & 23.2 & 3.8 \\
Rubus coreanus & 17.6 & -4.8 & 6.1 \\
Raphnus sativus & 12.5 & 34.0 & 21.6 \\
Glycyrrhiza glabra & 14.9 & 13.9 & 0.7 \\
Raphanus sativus & 12.5 & 34.0 & 21.6 \\
Ginki biloba & -8.0 & 12.0 & 3.5 \\
\hline Glucose uptake inhy & &
\end{tabular}

${ }^{1)}$ Glucose uptake inhibitory effect (\%): The percentage of intestinal glucose uptake inhibition for each sample was calculated comparison with the control. The final concentration of each sample was $0.1 \mathrm{mg} / \mathrm{mL}$. Fr. A: cold water extract, Fr. B: methanol extract, Fr. C: hot water extract. forms. The edible part of PG is rich in polyphenolic compounds such as anthocyanins and hydrolysable tannins. There are several reports showing that some polyphenols reduce glucose uptake (21-23). We therefore attempted to isolate and purify the active compound from PG. The methanol extract of PG (CM) with an inhibitory effect on intestinal glucose uptake from the Caco-2 cells was subsequently refluxed 4 times with hexane $(\mathrm{M}-\mathrm{H})$, chloroform (M-C) and ethyl acetate (M-E) to fractionate each solvent-soluble compound. The final residue (M-M) was dried. The methanol residue fraction (M-M) that showed the highest inhibitory effect $(45 \pm 2 \%$, Fig. 1) on glucose uptake in Caco-2 cells was chromatographed on the silica gel column yielding 18 sub-fractions. Among them, subfraction 4 (M-Ma) was found to inhibit glucose uptake by more than $40 \%$ ( $43 \pm 2 \%$, Fig. $2 \mathrm{~A})$, and was further chromatographed on second silica gel column to yield 26 sub-fractions. Fraction $12(\mathrm{M}-\mathrm{Mb})$ showing the highest inhibitory effect $(52 \pm 2 \%$, Fig. $2 \mathrm{~B})$ on intestinal glucose uptake and was further chromatographed on preparative ODS TLC. Five bands (PG-1 PG-5) were isolated and monitored for the glucose uptake inhibitory effect in Caco-2 cells. As depicted in Fig. 3, PG-1 with an $\mathrm{R}_{f}$ value of 0.43 exhibited a marked inhibitory effect $(75 \pm 3 \%)$, which was 1.4 - and 2.0 -fold of $\mathrm{M}-\mathrm{Mb}$ (active fraction obtained by the 2 nd silica gel column chromatography) and CM (methanol extract of PG), respectively.

To purify the active component of the intestinal glucose uptake inhibitor, the selected fraction from the TLC plate (PG-1) was subjected to $\mu$-Bondapak ${ }^{\mathrm{TM}} \mathrm{C}_{18}$ reverse phase column with an HPLC system. The final isolated compound, PG1-a, showed a significant single peak and

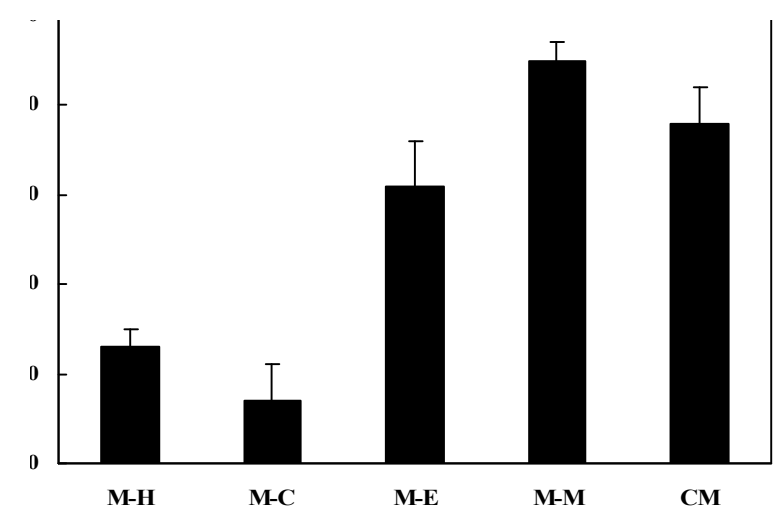

Fig. 1. Inhibitory effects of Punica granatum extract fractionated by solvent partitioning on intestinal glucose uptake in Caco-2 cell. The glucose uptake inhibitory activity for each fraction was calculated as the \% of the control activity (100\%). Final concentration of sample was $0.1 \mathrm{mg} / \mathrm{mL}$. Data represent the mean $(n=3) \pm$ SD. M-H: hexane extract, M-C: chloroform extract, M-E: ethyl acetate extract, M-M: methanol extract. 


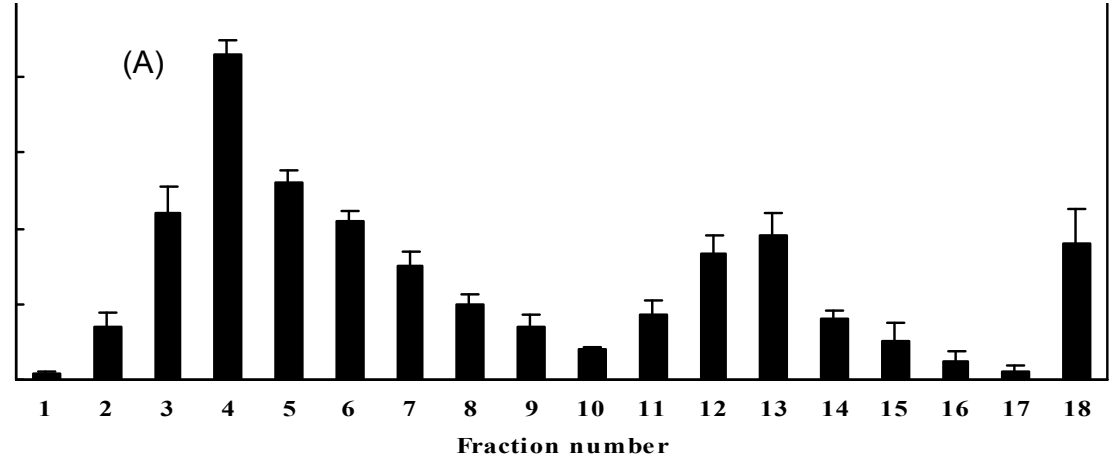

Fraction number

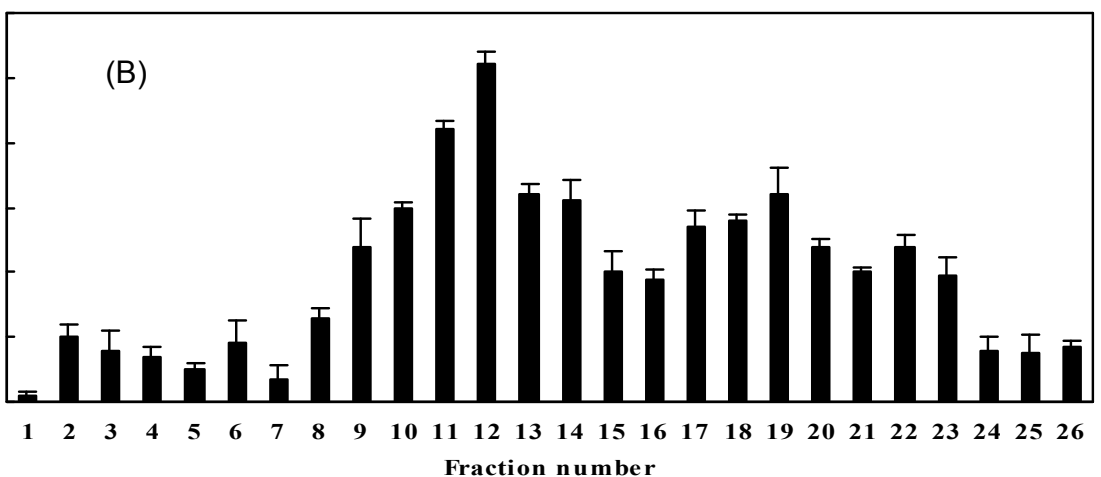

Fig. 2. Inhibitory effect of (A) M-M and (B) M-Ma subfractions separated by the silica gel open column chromatography on intestinal glucose uptake in Caco-2 cell. M-M: methanol extract, M-Ma: subfraction 4 of (A). A: Eluants were mixtures of $\mathrm{CHCl}_{3}$ and $\mathrm{MeOH}(100: 0$ (No. 1, 2), 80:20 (No. 3 5), 70:30 (No. 6, 7), 60:40 (No. 8, 9), 50:50 (No. 10, 11), 40:60 (No. 12, 13), 30:70 (No. 14, 15), 20:80 (No. 16, 17), 0:100 (No. 18); $\mathrm{v} / \mathrm{v})$. B: Eluants were mixtures of $\mathrm{CHCl}_{3}$ and $\mathrm{MeOH}$ (100:0 (No. 1), 85:15 (No. 2), 83: 17 (No. 3 8), 80:20 (No. 9 14), 77:23 (No. 15 20), 75:25 (No. 2 1 23), 70: 30 (No. 24, 25), 0:100 (No. 26); v/v). Sample concentration was 0.1 $\mathrm{mg} / \mathrm{mL}$. Data represent the mean $(n=3) \pm S D$.

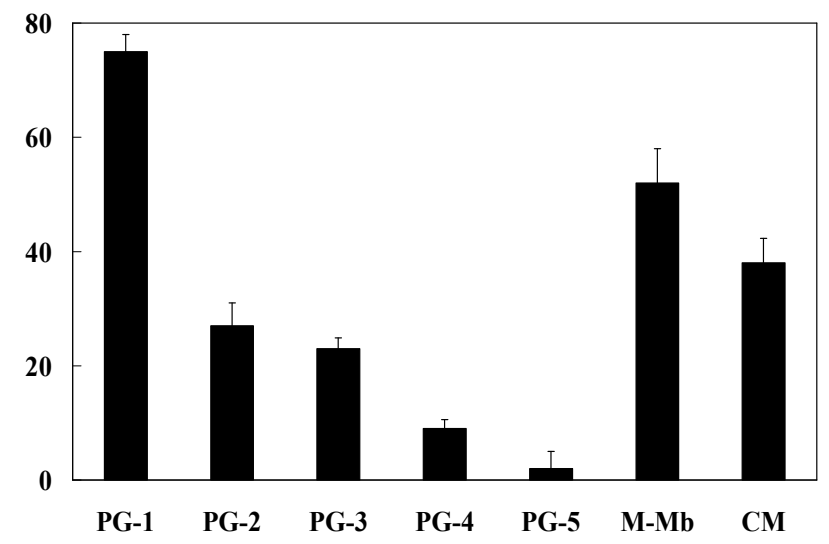

Fig. 3. Inhibitory effects of Punica granatum extract subfractions separated by the preparative TLC on intestinal glucose uptake in Caco-2 cell. TLC was carried out on ODS gel plate with methanol and water $(4: 1)$ solvent system and detected with UV lamp $(256 \mathrm{~nm})$. The glucose uptake inhibitory activity for each fraction was as the \% of the control activity (100\%). PG-1 PG-5: Fractions separated by the TLC, M-Mb: active fraction obtained by the second silica gel open column chromatography, CM: methanol extract of Punica granatum. The concentration of sample was $0.1 \mathrm{mg} / \mathrm{mL}$. Data represent the mean $(n=3) \pm \mathrm{SD}$.

spot on HPLC (Fig. 4A) and TLC (Fig. 4B), respectively. To identify the structure of this compound, the ${ }^{13} \mathrm{C} /$ ${ }^{1} \mathrm{H}-\mathrm{NMR}$, FAB-MS, and EI-MS assays were performed. Based on the combination with spectral data obtained

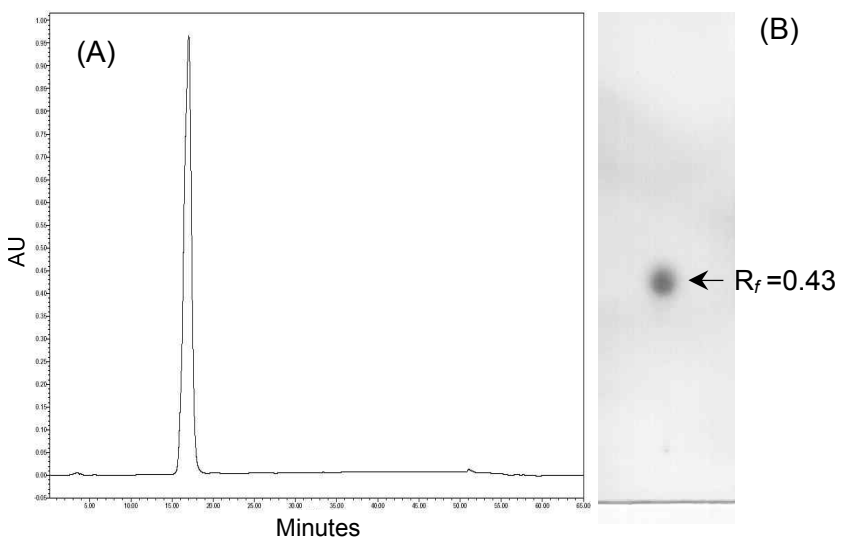

Fig. 4. HPLC (A) and thin-layer chromatography analysis (B) of the PG-1a, intestinal glucose uptake inhibitor isolated from Punica granatum. The HPLC analysis was performed with a Waters 2690 system equipped with a UV detector (at $228 \mathrm{~nm}$ ). The column $(7.8 \times 300 \mathrm{~mm})$ was eluted with the linear gradient of $90 \sim 100 \%$ methanol in distilled water at a flow rate of 2.0 $\mathrm{mL} / \mathrm{min}$. Injection volume was $60 \mu \mathrm{L}$. For TLC analysis, $1 \mu \mathrm{L}$ (1/10 dilution in $\mathrm{MeOH}$ ) sample was spotted on the ODS gel plate and developed with the solvent of methanol and water $(4: 1, \mathrm{v} / \mathrm{v})$. PG-1a was visualized with $5 \% \mathrm{H}_{2} \mathrm{SO}_{4}$ in $\mathrm{EtOH}(\mathrm{v} / \mathrm{v})$.

by NMR and mass spectrometry, PG-1a is speculated to be a phthalic acid diester compound. In the FAB-MS and EI-MS, two peaks corresponding to $[\mathrm{M}+\mathrm{H}]^{+} 419 \mathrm{~m} / \mathrm{z}$ and $[\mathrm{M}+\mathrm{Na}]^{+} 441 \mathrm{~m} / \mathrm{z}$ were observed, suggesting the 

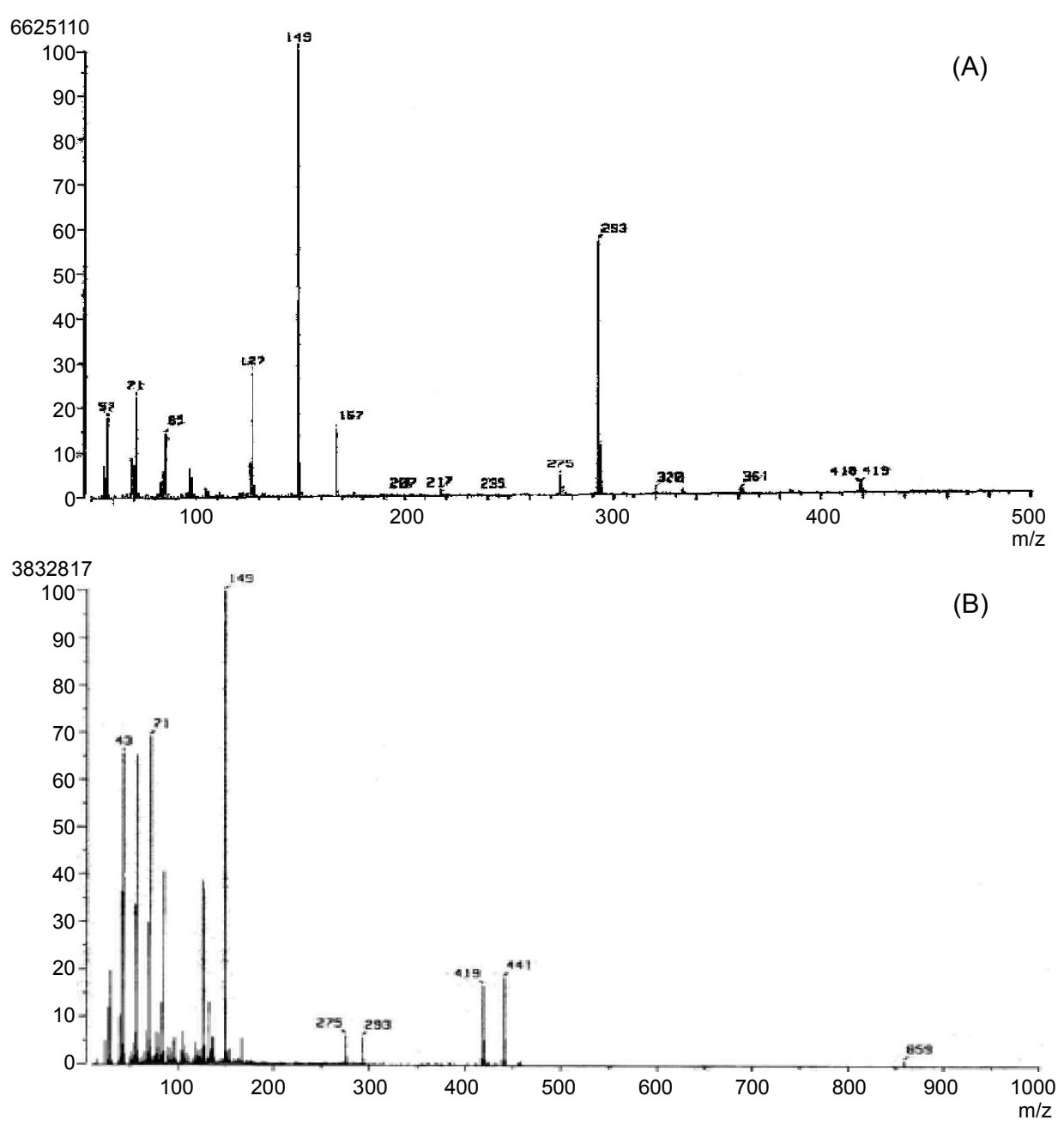

Fig. 5. EI-MS spectrum (A) and FAB-MS spectrum (B) of PG-1a isolated from Punica granatum. The spectrum was recorded on positive ion EI mass spectrometer and on positive ion $\mathrm{FAB}$ mass spectrometer.

molecular weight of PG-1a to be 418 (Fig. 5). The base peak $(149 \mathrm{~m} / \mathrm{z})$ of EI-MS suggested the presence of phthalic acid residue (Fig. 5A). The ${ }^{1} \mathrm{H}-\mathrm{NMR}$ spectrum (Fig. 6A) exhibited characteristic peaks, including aromatic proton signals (7.7 and $7.6 \mathrm{ppm}$ ) and many substituted aliphatic protons $(0.8 \sim 1.7 \mathrm{ppm})$. The ${ }^{13} \mathrm{C}-\mathrm{NMR}$ spectrum (Fig. 6B) showed several informative signals comprising ester carbonyl carbon (169.4 ppm) and hydroxylated aliphatic carbon (67.3, 67.0 ppm). The compound PG-1a did not exhibit TLC-color reactions with $\mathrm{FeCl}_{3}$, ninhydrin and bromocresal green, which is in good agreement with the results of the NMR and mass spectrometer data. In the current study, we speculated that PG-1a is a phthalic acid-diisononyl ester-like compound. PG-1a showed no cytotoxicity on rat enterocytes at concentrations of 100,200 , and $500 \mu \mathrm{g} / \mathrm{mL}$ (data not shown).

To confirm the inhibitory effect of PG-1a on intestinal glucose uptake, we examined the 2-NBDG uptake in Caco-2 cells. PG-1a showed dose dependent inhibitory effect with $89 \pm 5 \%$ inhibition of glucose uptake at 100 $\mu \mathrm{g} / \mathrm{mL}$ concentration as compared to control (Fig. 7). The effect of PG-1a was 2.3-fold higher than methanol extract of PG (CM). Furthermore, PG-1a showed a 1.2-fold higher inhibitory effect than phlorizin, which is known as a classical inhibitor of glucose uptake at the same concentration. The yields and $\mathrm{IC}_{50}$ values are listed in Table 2. The $\mathrm{IC}_{50}$ values of PG-1a and phlorizin on intestinal glucose uptake in Caco-2 cell assay system were $56.2 \mu \mathrm{g} / \mathrm{mL}$ and $66.7 \mu \mathrm{g} / \mathrm{mL}$, respectively.

Inhibition of intestinal glucose uptake would be beneficial for glucose homeostasis. Currently, a number of strategies are used to treat diabetes, such as $\alpha$-glucosidase inhibitors and/or inhibition of glucose uptake in the intestine (24). $\alpha$-Glucosidase inhibitors, such as acarbose and miglitol, which inhibit the breakdown of complex carbohydrates into simple sugars, work only with a meal containing complex carbohydrates $(5,25)$. On the other hand, PG-1a isolated in our study was found to inhibit the intestinal absorption, which could compensate for the limitations of current $\alpha$-glucosidase inhibitors.

We propose that the PG-1a might affect the sodium-dependent glucose co-transporter (SGLT)-1 gene expression. We have previously reported that PG treat- 


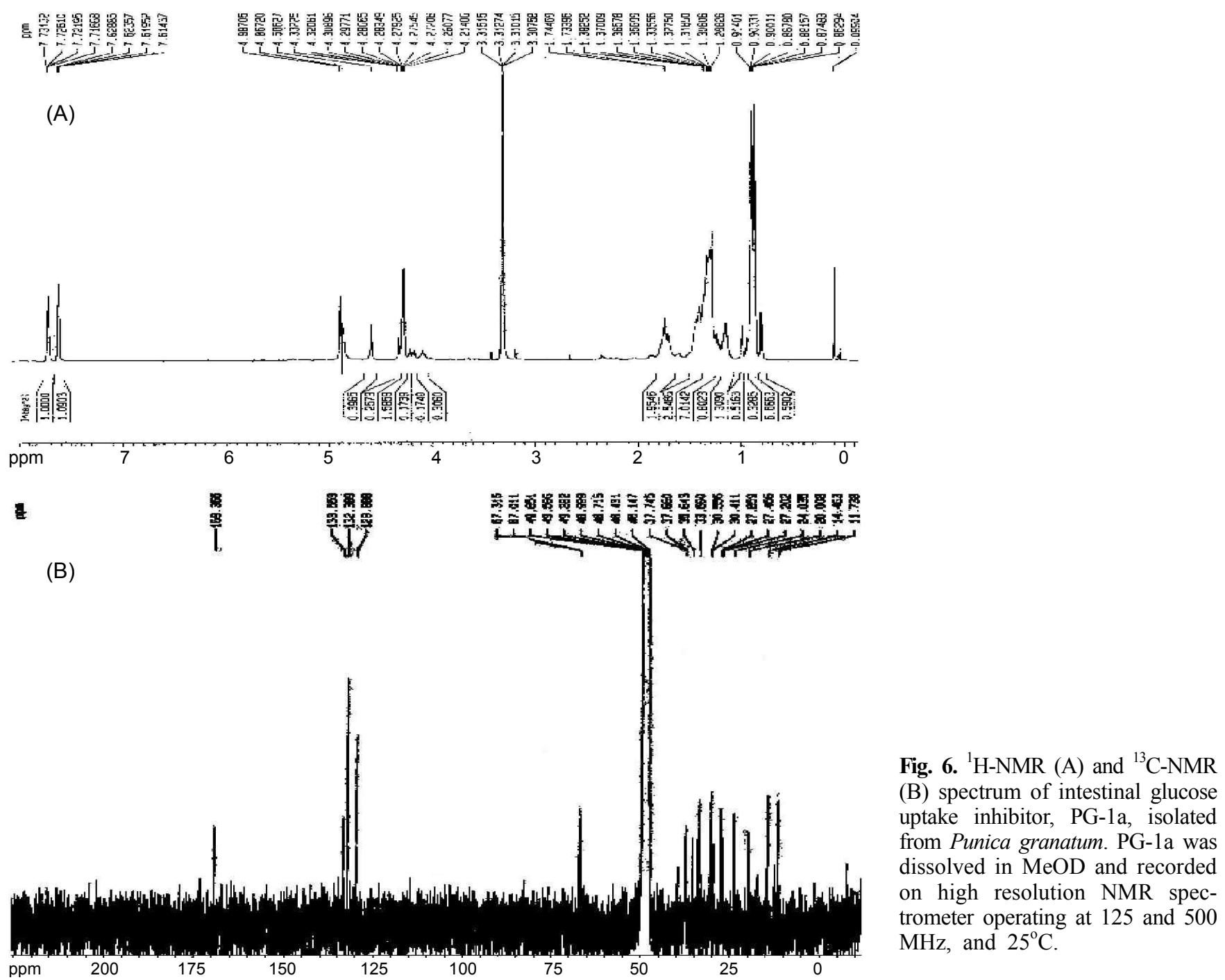

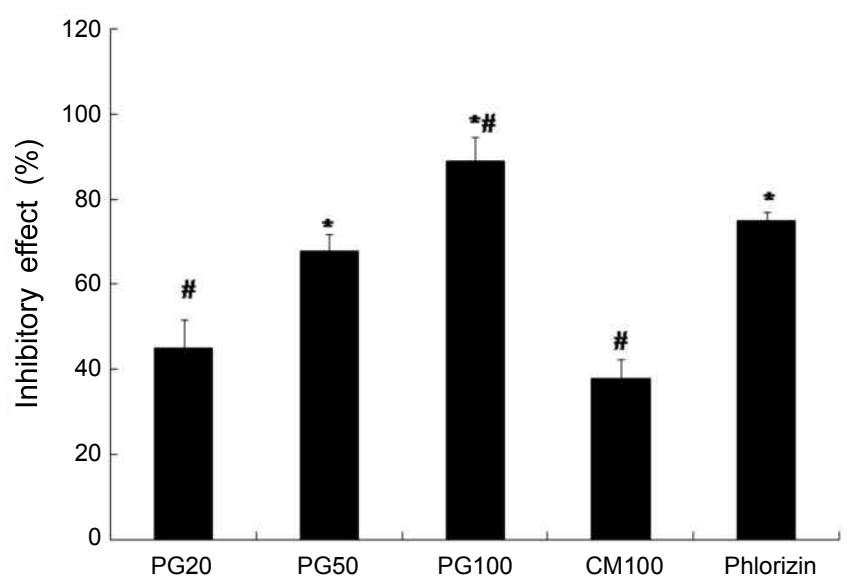

Fig. 7. Inhibitory effect of intestinal glucose uptake inhibitor, PG-1a, isolated from Punica granatum in Caco-2 cell. The glucose uptake inhibitory activity for each fraction was calculated as the $\%$ of the control activity (100\%). CM: methanol extract of Punica granatum, Phlorizin: Classical inhibitor of SGLT1. The concentrations of PG-1a were 20, 50, and 100 $\mu \mathrm{g} / \mathrm{mL}$. CM and phlorizin were $100 \mu \mathrm{g} / \mathrm{mL}$. Data represent the mean $(n=3) \pm \mathrm{SD} .{ }^{*} \mathrm{p}<0.05$ vs. $\mathrm{CM},{ }^{*} \mathrm{p}<0.05$ vs. phlorizin. ment reduced the SGLT1 protein expression in Caco-2 cells and SGLT1 activity in brush border membrane vesicles obtained from the mice small intestine after PG treatment (26). In terms of glucose transporter inhibitors, phlorizin and its analogs have been developed for use in diabetes and show potential for clinical application (27), and phthalic acid-diisononylester exhibited more potent effect than phlorizin.

Table 2. Yield and $\mathrm{IC}_{50}$ of intestinal glucose uptake inhibitor, PG-1a, isolated from Punica granatum

\begin{tabular}{lcc}
\hline & Yield $(\%)$ & $\mathrm{IC}_{50}(\mu \mathrm{g} / \mathrm{mL})^{1)}$ \\
\hline CM (methanol extract) & 60 & 131.6 \\
M-M (fractionated & 45 & 111.1 \\
$\quad$ methanol extract) & & \\
M-Ma (first silica gel) & 17.8 & 116.3 \\
M-Mb (second silica gel) & 7 & 96.2 \\
PG-1 (preparative TLC) & 2 & 68.7 \\
PG-1a (preparative HPLC) & 0.3 & 56.2 \\
\hline
\end{tabular}

${ }^{1)} \mathrm{IC}_{50}=$ The concentration required for $50 \%$ inhibition of intestinal glucose uptake. 
In conclusion, our results suggest that phthalic aciddiisononyl ester-like compound isolated from Punica granatum L. might perform a potent inhibitory activity in intestinal glucose uptake, indicating the need to further elucidate the mechanism underlying the action of phthalic acid-diisononylester.

\section{ACKNOWLEDGEMENTS}

This work was supported by a grant from the 2010 Fundamental R\&D Program of Hanseo University, and the Grant of the Korean Ministry of Education, Science and Technology (The Regional Core Research Program/ Zero Energy Green Village Technology Center).

\section{REFERENCES}

1. Wysham CH. 2010. New perspectives in type 2 diabetes, cardiovascular risk, and treatment goals. Postgrad Med 122: $52-60$.

2. Jenkins DJ, Kendall CW, Augustin LS, Martini MC, Axelsen M, Faulkner D, Vidgen E, Parker T, Lau H, Connelly PW, Teitel J, Singer W, Vandenbroucke AC, Leiter LA, Josse R. 2002. Effect of wheat bran on glycemic control and risk factors for cardiovascular disease in type 2 diabetes. Diabetes Care 25: 1522-1528.

3. Hara Y, Honda M. 1990. The inhibition of $\alpha$-amylase by tea polyphenols. Agric Biol Chem 54: 1939-1945.

4. Kim YM, Wang MH, Rhee HI. 2004. A novel alpha-glucosidase inhibitor from pine bark. Carbohydr Res 339: 715-717.

5. Bischoff H. 1994. Pharmacology of alpha-glucosidase inhibition. Eur J Clin Invest 3: 3-10.

6. Anesini C, Perez C. 1993. Screening of plants used in Argentine folk medicine for antimicrobial activity. $J$ Ethnopharmacol 39: 119-128.

7. Ponce-Macotela M, Navarro-Alegría I, Martínez-Gordillo MN, Alvarez-Chacón R. 1994. In vitro effect against Giardia of 14 plant extracts. Rev Invest Clin 46: 343-347.

8. Zhang J, Zhan B, Yao X, Gao Y, Shong J. 1995. Antiviral activity of tannin from the pericarp of Punica granatum L. against genital Herpes virus in vitro. Zhongguo Zhong Yao Za Zhi 20: 5586-5588.

9. Mavlyanov SM, Islambekov SY, Karimdzhanov AK, Ismailov AI. 1997. Polyphenol of pomegranate peels show marked anti-tumor and anti-viral action. Khim Prir Soedin 33: 124-126.

10. Jafri MA, Aslam M, Javed K, Singh SL. 2000. Effect of Punica granatum Linn. (flowers) on blood glucose level in normal and alloxan-induced diabetic rats. J Ethnopharmacol 70: 309-314.

11. Aviram M, Dornfeld L, Rosenblat M, Volkova N, Kaplan M, Coleman R, Hayek T, Presser D, Fuhrman B. 2000. Pomegranate juice consumption reduces oxidative stress, atherogenic modifications to LDL, and platelet aggregation: studies in humans and in atherosclerotic apolipoprotein E-deficient mice. Am J Clin Nutr 71: 1062-1076.

12. Mahraoui L, Rodolosse A, Barba A, Dussaulx E, Zwei- baum A, Rousset M, Brot-Laroche E. 1994. Presence and differential expression of SGLT1, GLUT1, GLUT2, GLUT3 and GLUT5 hexose-transporter mRNAs in Caco-2 cell clones in relation to cell growth and glucose consumption. Biochem J 298: 629-633.

13. Leira F, Louzao MC, Vieites JM, Botana LM, Vieytes MR. 2002. Fluorescent microplate cell assay to measure uptake and metabolism of glucose in normal human lung fibroblasts. Toxicol In Vitro 16: 267-273.

14. Zou C, Wang Y, Shen Z. 2005. 2-NBDG as a fluorescent indicator for direct glucose uptake measurement. $J$ Biochem Biophys Methods 64: 207-215.

15. Alonso-Castro AJ, Miranda-Torres AC, González-Chávez MM, Salazar-Olivo L. 2008. Cecropia obtusifolia Bertol and its active compound, chlorogenic acid, stimulate 2 NBDglucose uptake in both insulin-sensitive and insulinresistant 3T3 adipocytes. J Ethnopharmacol 120: 458-464.

16. Alonso-Castro AJ, Salazar-Olivo LA. 2008. The anti-diabetic properties of Guazuma ulmifolia Lam are mediated by the stimulation of glucose uptake in normal and diabetic adipocytes without inducing adipogenesis. $J$ Ethnopharmacol 118: 252-256.

17. Gaudreault N, Scriven DR, Laher I, Moore ED. 2008. Subcellular characterization of glucose uptake in coronary endothelial cells. Microvasc Res 75: 73-82.

18. Leira F, Louzao MC, Vieites JM, Botana LM, Vieytes MR. 2002. Fluorescent microplate cell assay to measure uptake and metabolism of glucose in normal human lung fibroblasts. Toxicol In Vitro 16: 267-273.

19. Louzao MC, Vieytes MR, Fontal O, Botana LM. 2003. Glucose uptake in enterocytes: a test for molecular targets of okadaic acid. J Recept Signal Transduct Res 23: 211224.

20. Ball SW, Bailey JR, Stewart JM, Vogel CM, Westcott SA. 2002. A fluorescent compound for glucose uptake measurements in isolated rat cardiomyocytes. Can J Physiol Pharmacol 80: 205-209.

21. Hanamura T, Mayama C, Aoki H, Hirayama Y, Shimizu M. 2006. Antihyperglycemic effect of polyphenols from Acerola (Malpighia emarginata DC.) fruit. Biosci Biotechnol Biochem 70: 1813-1820.

22. Cermak R, Landgraf S, Wolffram S. 2004. Quercetin glucosides inhibit glucose uptake into brush-border-membrane vesicles of porcine jejunum. Br J Nutr 91: 849-855.

23. Johnston K, Sharp P, Clifford M, Morgan L. 2005. Dietary polyphenols decrease glucose uptake by human intestinal Caco-2 cells. FEBS Lett 579: 1653-1657.

24. Wagman AS, Nuss JM. 2001. Current therapies and emerging targets for the treatment of diabetes. Curr Pharm Des 7: 417-450.

25. Yee HS, Fong NT. 1996. A review of the safety and efficacy of acarbose in diabetes mellitus. Pharmacotherapy 16: $792-805$.

26. Kim HK, Baek SS, Cho HY. 2011. Inhibitory effect of pomegranate on sodium dependent glucose uptake. $\mathrm{Am} J$ Chin Med In press.

27. Oku A, Ueta K, Nawano M, Arakawa K, Kano-Ishihara T, Matsumoto M, Saito A, Tsujihara K, Anai M, Asano T. 2000. Antidiabetic effect of T-1095, an inhibitor of $\mathrm{Na}(+)$-glucose cotransporter, in neonatally streptozotocintreated rats. Eur J Pharmacol 391: 183-192. 